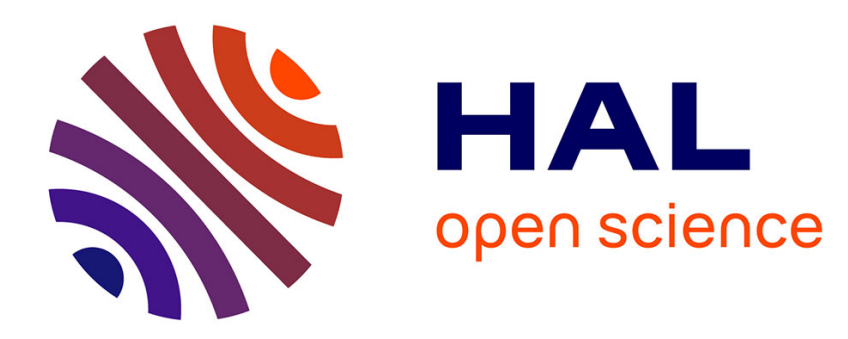

\title{
Plastic behavior of prestrained metals: microstructural aspects.
}

\author{
J.L. Raphanel, J.-H. Schmitt
}

\section{To cite this version:}

J.L. Raphanel, J.-H. Schmitt. Plastic behavior of prestrained metals: microstructural aspects.. Revue de Physique Appliquée, 1988, 23 (4), pp.708-708. 10.1051/rphysap:01988002304070800 . jpa00245864

\section{HAL Id: jpa-00245864 https://hal.science/jpa-00245864}

Submitted on 1 Jan 1988

HAL is a multi-disciplinary open access archive for the deposit and dissemination of scientific research documents, whether they are published or not. The documents may come from teaching and research institutions in France or abroad, or from public or private research centers.
L'archive ouverte pluridisciplinaire HAL, est destinée au dépôt et à la diffusion de documents scientifiques de niveau recherche, publiés ou non, émanant des établissements d'enseignement et de recherche français ou étrangers, des laboratoires publics ou privés. 


\section{PLASTIC BEHAVIOR OF PRESTRAINED METALS: MICROSTRUCTURAL ASPECTS.}

J.L. RAPHANEL and J.-H. SCHHITT

Laboratoire Génie Physique et Mécanique des Matériaux,

Unité Associée au CNRS 793, GRECO CNRS "Grandes Déformations et Endommagement" ENSPG -B.P.46- F 38402 Saint Martin d'Hères FRANCE

The plastic behavior of prestrained materials is often studied from a purely mechanical and macroscopical point of view. These approaches include phenomenological accounts of hardening and of initial as well as induced anisotropy. They lead to the construction of macroscopic yield surfaces and to the modifications of these surfaces with strain histories.

From a physical viewpoint, a plastic deformation induces microstructural evolutions. For a polycrystalline single phase metal which deforms by intragranular glide, several previous investigations have shown that the two most influent structural features are:

- the crystallographic texture, both the initial texture and the one developed during plastic deformation,

- the intragranular substructures, such as arrangements of dislocations in walls delimiting dislocation free zones inside the grain.

The aim of this approach which is based on a metallurgical analysis is twofold. On the one hand, one seeks to determine the respective roles played by the structural factors in several situations of change of deformation path; on the other hand, one shall show the limits of the standard assumption of homogeneous behavior of a prestrained metal.

The prestrain has favored within the grains the activity of some slip systems and thus built specific dislocation substructures $/ 1 /$. A way to account for the macroscopical effect of these structures on the subsequent yield stress is to introduce latent hardening and Bauschinger effect for each crystallite. The simulation of the response of the polycrystal is then carried out by using a Taylor model $/ 2 /$. One may in this way determine sections of the polycrystal yield locus with an account of anisotropic intragranular structures and one is also able to predict the subsequent yield stress of a prestrained material subjected to new deformation paths. These last results are compared with experimental data obtained for low carbon steel prestrained in uniaxial tension and subjected to uniaxial tensions along other axes /3/ (figure 1) or simple shears about various orientations /4/ (figure 2). The model is in good agreement with the variation of the subsequent yield stress for the various paths. This agreement was not achieved with a model taking account of textures alone. For instance, one is able to account, at least partially, for the development of a Bauschinger effect that appears in simple shear along some particular orientations.

When one wishes to describe the behavior of prestrained material beyond the subsequent yield stress, one has to be certain that the plastic deformation is uniform along the whole sample. It is indeed observed that for the larger prestrains, or even at moderate prestrain for some changes of deformation paths, the plastic deformation takes place in a small part of the specimen only /5/. A macroscopic localization appears then very rapidly, in the form of bands. At a microscopic level, one may observe in some grains microbands which correspond to unstable evolutions of substructures /6/, although no quantitative correlation has been made so far, between the microscopic and macroscopic instabilities.

This last point shows clearly that experimental stress-strain curves of prestrained materials are in many cases an average representation of the behavior of a material that may be deforming in a very heterogeneous way. A comprehensive description of the macroscopic behavior of prestrained materials should include an understanding and an account of the evolutions of intragranular structures.

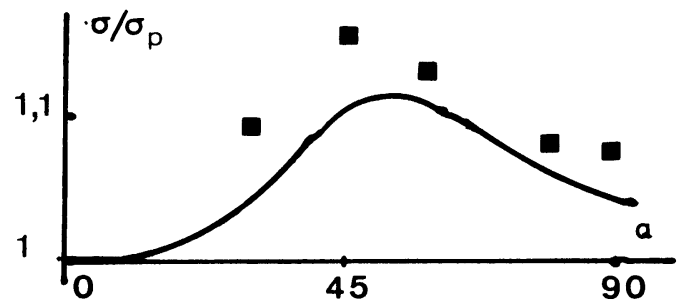

Figure 1: Sequences of uniaxial tensions

Ratios of subsequent yield stresses at $\alpha$ and 0 degree with $\alpha$, angle between the tensile axes; simulation and experimental points (a) after a prestrain $\varepsilon_{1}=0.15$.

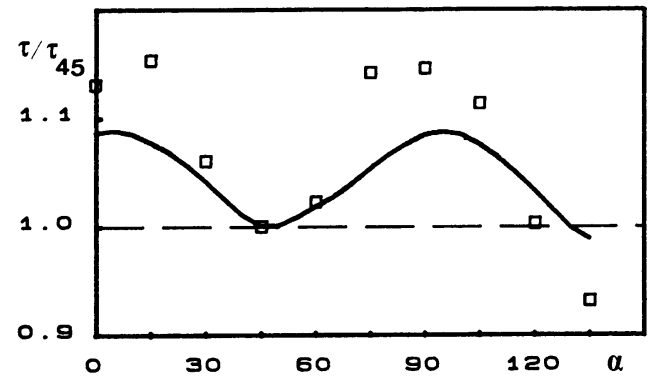

Figure 2: Sequences uniaxial tension-simple shear Ratios of subsequent yield shear stresses at $\alpha$ and 45 degrees with $\alpha$, angle between the tensile axis and a direction of positive shearing; simulation and experimental points $(\square)$ after a prestrain $\varepsilon_{1}=0.15$.

\section{References}

/1/ FERNANDES, J.V. and SCHMITT, J.-H., Phil. Mag. A, 48, 841, 1983.

/2/ VAN HOUTTE, P. and AERNOUDT, E., Z. Metalkde, 66, 202, 1974.

/3/ RAPHANEL, J.L., SCHMITT, J.-H. and BAUDELET B. Int. J. of Plasticity, 2, 371, 1986.

/4/ RAPHANEL, J.L., RAUCH, E., SHEN, E.L. and SCHMITT, J.-H., Scripta Metall., to be published, 1987.

/5/ KORBEL, A. and MARTIN, P., Acta Metall., to be published, 1987.

'6/ SCHMITT, J.-H. and BAUDELET, B., Proc. ICSMA 7, Montreal, Pergamon Press, 1, 213, 1985. 